\title{
The Determinants of Migration: Italian Regional Factors and the Relationship with Filipino Migrant Labor Supply
}

\author{
Maire Carroline Magantea
}

Received: 15.08.2019; Revised: 18.11.2019; Accepted: 27.12.2019

\begin{abstract}
Throughout the years, the segmentation of the Italian labor market across regions, classes, genders, skill-levels and sectors has benefited from the supply of migrant labor. Among these migrant laborers, Filipinos met the demand for labor across various sectors where native supply is insufficient for local demand. Nevertheless, despite demand, the migration inflow fluctuates in response to variations in economic and geographic conditions. This study investigates the region-specific drivers of the annual inflow of Filipino migrants to the various regions in Italy. Using the annual arrivals of labor migrants from the Philippines to Italy for the period of 2007-2017, this paper uses static and dynamic estimation techniques by utilizing regional economic and demographic indices. The results show adherence to and diversion from migration theories and expected movements. Regardless of the substantial regional differences, the Filipino migrant stock is the most stable and significant variable in influencing regional migration inflow.
\end{abstract}

JEL codes: C23, F22, R23, P25

Keywords: Economic migration, Philippines, Italy, Regional differences

\section{Introduction}

In Italy, recent declines in the overall population and substantial numbers of emigration have led to labor shortages within particular sectors. The falling population is only made stable by the immigration of foreign laborers. Labor migration has helped to meet the need for low-skilled labor in the manufacturing, social and domestic services and healthcare sectors in particular (Riva \& Zanfrini, 2013). Most migrants are employed in sectors where competition with the native population is low, and consequently, there is greater access to the job market (Riva \& Zanfrini, 2013). In Italy, migrants represent $10 \%$ of the workforce, the largest sources of which are Romania, Albania, Morocco, China, Ukraine and the Philippines.

In 2007, Filipino labor migrants comprised around $3.8 \%$ of the total labor migrant population from non-EU countries in Italy (the Istituto Nazionale di Statistica - ISTAT). Between 2007 and 2017, significant fluctuations were observed in the immigration of Filipino labor

a Department of Social Sciences, Gran Sasso Science Institute, Viale Francesco Crispi, 7, L'Aquila, Italy. e-mail: mairecarroline.magante@gssi.it. (D) https://orcid.org/0000-0001-9008-118X 
to Italy. The biggest decrease in the percentage of Filipino migrant laborers in total labor migrant population from non-EU countries was in 2013: from $5.58 \%$ to $2.27 \%$. The share continued to fall until it reached $1.43 \%$ in 2017. In figures, the total number of Filipino labor migrants entering Italy dropped from 5,726 in 2007 to as little as 175 in 2017, which represents a $96.94 \%$ drop over the eleven years.

This significant reduction in the Filipino labor migration flow to Italy is a problem worth to analyze. The aims of this research are to investigate what region-specific indicators affect the Filipino labor migrant inflow and how responsive is Philippine labor migrant flow to non-wage determinants of migrant labor. To this end, regional data from 2007 to 2017 for twenty regions in Italy are analyzed by using static and dynamic estimation techniques.

This paper contributes to the existing debate regarding the various reasons that cause the relative inelasticity of migration in Europe. Eichengreen (1993) and Obstfeld \& Peri (1999) cite that the elasticity of migration to various indicators such as regional wage and differences in unemployment in Europe is less responsive. On the other hand, Bertola (2000) cites the inadequate mobility of labor and restrictive wages that contribute to the variances in unemployment in Europe. Niebuhr (2003) meanwhile, argues that although the labor migration studies primarily consider topics such as the adjustments in the labor markets as brought about by migration and the consequences to labor market destination, few studies take into consideration the spatial dimension. Consequently, it is only through including migration in the discussion that the spatial dimensions of the labor market are considered. Hence, the studies that purposely deliberated on the labour markets particularly on the spatial dimension are rather limited. In this way, this paper contributes to the analysis of location-specific factors. By excluding the location-specific factors, particularly at a smaller scale, there is less understanding of the reasons for migration, or even migration variation.

This paper also contributes to the literature focusing on the Filipino migration diaspora in Italy. Among the related findings, papers of McKenzie et al. (2014) and Yang (2008) relate to the immigration side of the study. Biagi et al. (2011) and Etzo (2011) are also utilized to include the Italian perspective. McKenzie et al. (2014) studies the land departures of temporary Filipino migrant workers in relation to wages available in various destination countries for the given fluctuations in the gross domestic product (GDP). In the research by Etzo (2011), the findings conclude that the migrants respond to the same variable differently. Regardless, there is still an opportunity to examine the specific migrant ethnicity reactions to smaller-scale indicators. As such, the lack of understanding of the Filipino labor migrants' reaction to a specific country's regional indicators still remains unfilled. This paper aims to fill that gap by exploring the geographic and economic factors at a local scale that drives Filipino migrant flows. Finally, this paper also contributes to the stream of research that studies social and family capital and its role in influencing economic activities. As argued by Biagi \& Dotzel (2018), further research should focus on the role of social and family capital and how it impacts migration. This research would also be relevant to economic research that deals with migration issues from emerging or developing economies to developed countries.

The remainder of this paper is structured as follows. Section 2 reviews the literature. Section 3 briefly describes the dataset and the research design. Section 4 presents the results. Finally, section 5 draws the discussion to a conclusion. 


\section{Literature Review}

This section reviews the previous literature, which has sought to explain the PhilippinesItalian labor migration phenomenon. In particular, it firstly focuses on the studies employing economic models to select the variables used and model applied in this study. Secondly, the paper reviews the background context and push factors such as the migration policies in the Philippines which largely facilitated the continuous outmigration of Filipino labor migrants. Thirdly, the paper addresses the demand side factors, by exploring previous literature which analyses the role of migrants in the Italian labor market, with a focus on the distribution of Filipino labor migrants across regions. Finally, the literature review concludes with a discussion of the economic geography of Italy by focusing on the analysis of the differences in the distribution of employment opportunities and labor, and their potential effect on differences in Filipino labor migrant distribution across regions.

\subsection{Relevant Models of Labor Migration}

Since there is no overarching theory of labor migration, researchers employ various theories and models to explain the phenomenon. The interest in investigating the push and pull factors of labor migration resulted in identifying various explanatory variables such as, but not limited to existing migrant population and potential wage (Bauer et al., 2005), wage differentials (Harris \& Todaro, 1970), cost and location of housing (Andersen et al., 2013; Sim, 2000; Potepan, 1994; Andersson \& Nilsson, 2011; van der Vlist et al., 2011), economic growth or recovery (Jennissen, 2004; Beets \& Willekens, 2009), and probability of employment (Reich et al., 1973; Massey et al., 1993; Jennissen, 2004; Harris \& Todaro, 1970).

In the case of Italy, the various determinants of migration flows, specifically interregional flows, are cited by the previous studies. The analysis focuses more on labor migrants from all countries rather than a specific nationality. The findings conclude that determinants change over time and location. In the 1950s and 1960s, Salvatore (1977) cites the differentials in unemployment rates and wages as the primary determinants of interregional migration. However, Furceri (2006) presents the regional variation and concludes that the unemployment rate does not affect migration for the period of 1985-2001. Other scholars such as Cannari et al. (2000) shows that the housing cost differentials serve as a deterrent for internal migration in Italy. Etzo (2011) cites migration being influenced by the "social networks", i.e. the existence of migrants from the same country in the regions, per capita GDP, and housing cost as significant determinants of migration flows, and unemployment rate and per capita GDP variances as push factors of migration from the home country. In short, there is no conclusive set of determinants of migration.

A distinguishing characteristic of international migration is the congregation in immigrant clusters, especially with the migrants' own ethnic background, to take advantage of having a network, which is also known as the Network Externalities Model (Bauer et al., 2005; Sanders \& Nee, 1987; Chiswick \& Miller, 2005). Ethnic enclaves and location clustering are known to influence the location choice of migrants, particularly for those who are in the initial adaptation phase (Bauer et al., 2005). These settlement concentrations or ethnic enclaves could be found in large cities and a good example of which is the Filipino migrant workers in Rome and Milan. The model presented in this research utilizes the total Filipino migrant population to predict the inflow of Filipino labor migration to contribute to the 
existing literature by studying the effect of social and family capital on migration and via the Networks Externality Model.

Buffer theory was popular in the 1950s to explain the influx of migrant laborers to European countries. This theory explains that in the periods of economic recovery, migrant laborers are expected to arrive in host countries to the increase in the number of vacant jobs (Beets \& Willekens, 2009). The theory predicts that migrant laborers flee the host country during the times of economic crisis and are expected to return to their home countries, and, in turn, free up jobs for the non-migrant population (Kuhn, 1978; Dobson et al., 2009). Economic growth affects the inflow of migrant laborers positively, while the economic recession decreases migrant labor flows (Jennissen, 2004). Adding to the work of Jennissen (2004), this paper uses real, i.e. in constant prices, GDP to represent the economic health of the country and to evaluate if real GDP indeed predicts the inflow of Filipino labor migrants.

The neo-classical theory holds that the probability of employment and wage differentials are the two most significant predictors of labor migration (Harris \& Todaro, 1970). The theory asserts that the chance of getting employed triggers the inflow of migrant labor. Aspiring labor migrates when the potential of getting a job and the variances in potential earnings in the host country are both high as compared to staying in their home countries. In this theory, employment and labor migration inflow are positively correlated: as the probability to be employed in a host country increases, the labor migration flow also increases, and, as unemployment rises the labor migration inflow to the host country decreases. To further examine this theory, this paper uses regional unemployment as an independent variable.

As justified by the previous literature, housing cost is a significant predictor of job growth and creation. Various scholars cite variables that affect housing cost such as migrants' economic standing and availability in local housing markets (Andersen et al., 2013), location (Sim, 2000), social instruments (Andersson \& Nilsson, 2011), and numerous housing restrictions in general (van der Vlist et al., 2011). In order to quantify the impacts of housing cost, it is included as an independent variable.

Based on the body of the research of other scholars, this paper employs regional real GDP, unemployment, housing cost, and total Filipino population to explain the changes in the Filipino labor migration flow into the Italian regions between 2007 and 2017. This paper tests the following hypotheses:

$\mathrm{H}_{0}$ : Higher real GDP leads to higher Filipino labor migrant inflow

$\mathrm{H}_{0}$ : Higher unemployment leads to lower Filipino labor migrant inflow

$\mathrm{H}_{0}$ : Higher housing costs lead to lower Filipino labor migrant inflow

$\mathrm{H}_{0}$ : Higher total Filipino population leads to higher Filipino labor migrant inflow

\subsection{The Philippine Government's Pro-Migration Stance and Agencies}

Around $2 \%$ of the population of the Philippines migrates abroad on average per each year for employment purposes, and nearly ten percent of the country's population is living and working abroad. Compensation elsewhere is high enough to offset the costs of migrating away from the country (McKenzie et al., 2010). The Philippine government plays an effective role in promoting labor migration as part of its national development strategy. With the patronage of the government and factory-like precision of employment agencies in producing successful migrant workers, the Filipinos are among the preferred choice for migrant labors across the world. 
Table 1: Distribution of Filipino Migrant Workers by Gender, \%

\begin{tabular}{lrrr}
\hline Age Group & Total & Male & Female \\
\hline 15 - 24 & 6.4 & 5.3 & 7.2 \\
$25-29$ & 20.4 & 16.0 & 24.1 \\
$30-34$ & 21.7 & 19.8 & 23.4 \\
35 - 39 & 18.1 & 18.6 & 17.6 \\
40 - 44 & 16.1 & 17.2 & 15.3 \\
45 and over & 17.3 & 23.1 & 12.4 \\
\hline Workplace & & & \\
\hline Africa & 1.1 & 2.4 & 0.1 \\
Asia & 85.5 & 77.3 & 92.7 \\
Australia & 1.6 & 2.3 & 0.9 \\
Europe & 6.4 & 10.1 & 3.1 \\
North and South America & 5.4 & 7.9 & 3.2 \\
\hline Major Occupation Group & & & \\
\hline Managers & 1.1 & 1.4 & 0.9 \\
Professionals & 8.7 & 8.3 & 9.0 \\
Technicians and associate professionals & 5.8 & 9.5 & 2.5 \\
Clerical support workers & 3.4 & 2.6 & 4.0 \\
Service and sales workers & 18.0 & 15.7 & 20.0 \\
Skilled agricultural forestry and fishery workers & 0.4 & 0.7 & 0.1 \\
Craft and related trades workers & 11.4 & 22.1 & 2.1 \\
Plant and machine operators and assemblers & 13.7 & 26.9 & 2.3 \\
Elementary occupations & 37.5 & 12.8 & 59.1 \\
\hline Source: PSA (2018). & & & \\
Note: Reference Period is April - September 2017. & & &
\end{tabular}

The massive demand for the Filipino workers in the Middle East in the 1970s combined with high rates of domestic unemployment led the president Ferdinand Marcos to institute labor exportation policies. Then, the policy was expanded to make the program more conducive to outmigration and to ensure the generated income is remitted back to the Philippines. The Marcos administration under the Executive Order 857 in 1982 mandated the Filipino laborers abroad to send their income back to the Philippines through governmentregulated channels. Remittances were called a "nationalist duty" by the Aquino government. The Ramos administration pushed for more migration, calling migrants "internationally shared human resources" (Rodriguez, 2010). The Estrada administration established an inter-agency committee on the shared government information system for migration (Executive Order No. 203 year 2000). In parallel to these policies, the Arroyo administration pushed the citizenship retention and enacted the reacquisition law which allows Filipinos to maintain dual citizenship (Republic Act 9225 in 2003).

There is an array of governmental agencies and privately-operated recruitment services that facilitate and regulate the placement and enlistment of workers abroad. Agencies such as the Overseas Employment Development Board (OEDB), the National Seaman Board (NSB) and the Bureau of Employment Services (BES) were created to support government initiatives on labor exportation. The functions of OEDB, NSB and BES were consolidated into one organization - the Overseas Employment Program Administration, which later became the Philippine Overseas Employment Administration (POEA). The POEA is an agency of the Philippine government whose numerous functions include helping Filipinos in looking for employment abroad, protecting and promoting the welfare of the Filipino workers and their families, and helping overseas Filipinos in distress. As of December 2019, 
there are 3,728 recruitment agencies that are being regulated by the POEA. The roles of these recruitment agencies mainly lie in serving as liaison to companies hiring abroad and facilitating the application processes until the potential labor migrant flies out to their country of destination.

The policy has had enormous success in facilitating job placement and remittances for several reasons. Firstly, English is one of the official languages of the country and is used as early as pre-school as a medium of instruction. Secondly, the government complemented its labor exporting strategy by setting up vocational training centers around the country specializing in skills targeting the global labor economy. Training centers, among many others, in caregiving, welding, housekeeping, food and beverage services, and electrical installations have served as platforms for getting skills to find a job in the local labor markets and abroad (TESDA, 2017). Aside from centers that provide technical training, universities in the Philippines are on par with international standards. Thirdly, the qualified professional graduates in the Philippines have comparatively lower wage rate in the international market. Finally, the abundance of these workers makes it ideal for foreign companies to hire them en masse. With the Philippines' seemingly unending supply of labor and continuous state of unemployment and underemployment, the huge reservoir of able-bodied laborers are easily utilized and ready to be sent to foreign countries.

\subsection{The Italian Reception and the Use of Labor Migrants}

The current economic climate in Italy and the country's stance towards migration, in general, could bring about detrimental effects to its labor market, most especially to the already high regional unemployment. Burridge \& Gordon (1981) suggests that migration brings balancing effects to regional unemployment.

Between 2007 and 2017, roughly 1.3 million labor migrants or approximately 117,000 labor migrants per year arrived in Italy (ISTAT). There are stark differences in both geographical and sectoral distribution of labor migrants. The majority of the employed labor migrants are concentrated in the northern regions. The level of employment of labor migrants in the southern regions of Italy is considerably low. The foreign workers are mainly concentrated in the regions of Trentino-Alto Aldige, Emilia Romagna and Tuscany, whereas the fewest number of foreign workers works in the regions of Sardinia, Sicily and Campania (Ministry of Labor and Social Policies, 2018). The labor migrants are heavily concentrated in the community and social services, hotels and restaurants services, agriculture, hunting and fishing, and construction sectors, and are the least concentrated in the public administration, defence and social security, finance and insurance, and information and communication sectors (Ministry of Labor and Social Policies, 2018).

The sectoral segregation of the labor migrants in low-skilled jobs may be influenced by the country's ethnicity-oriented immigration policy (Lindio-McGovern, 2003). An example of such policy is the adoption of a quota system that sets the numerical limits in issuing work permits for the specific nationalities and the purpose of stay. The decree then sets out the restrictions, detailed practices and other mandatory obligations in accordance with the work permit or visa. Immigration policies like this contribute significantly in influencing the segregation of the Filipino migrants into others such as domestic jobs. A good example is the situation of the Philippine migrant laborers in Rome. The dynamics that can be seen in many world cities like Rome impact the diversity of immigrants coming into these different cities: it is characterised by the increasing need for foreign laborers to take up 
low-skilled jobs (Sassen, 1991). Similarly, the segregation to the domestic service occupations is partially caused by the immigration policies that delegate these domestic jobs to those immigrants from non-EU countries. This prevents the occupational ascendency of non-Italians or other non-EU citizens to specific professions. These practices, combined with ethnicity-oriented geopolitics, indirectly classify migrants into low-ranking, low-paid employment (Lindio-McGovern, 2003). For example, despite most of the Filipino women employed in domestic work in Italy are degree holders, the immigration practices make it highly less likely for Filipino immigrants in occupational specialisation to upgrade into more professional employment. These immigration systems in place, therefore, at least hinder the occupational upgrading that Waldinger $(1994,1996)$ predicts.

\subsection{The Geographical Distribution of the Filipino Labor Migrants among the Italian Regions}

With the substantial decrease in the Filipino labor migrants coming to Italy, this subsection gives a short overview of the changes over time. Figure 1 shows the distribution of total Filipino migrant stock across Italian regions from the period of 2007-2017. At the beginning of the period under consideration, the highest number of Filipino settlement in Italy is concentrated in the region of Lombardy, followed by Lazio, Emilia Romana, and Tuscany. Less than a hundred Filipinos are reported to reside in the regions of Valle D' Aosta, Molise, and Campania. Although the total number of Filipinos in Italy is gradually increasing in general, a drop in the inflow can be seen in the year 2012 across most of the regions. The inflow of migrants raised in 2013 and experienced another drop in 2015. In the eleven-year period, the regions of Sardinia and Puglia experienced $157 \%$ and $129 \%$ growth in Filipino migrant population, respectively. Molise is the only region in Italy where a negative growth rate for the Filipino migrant population was recorded.

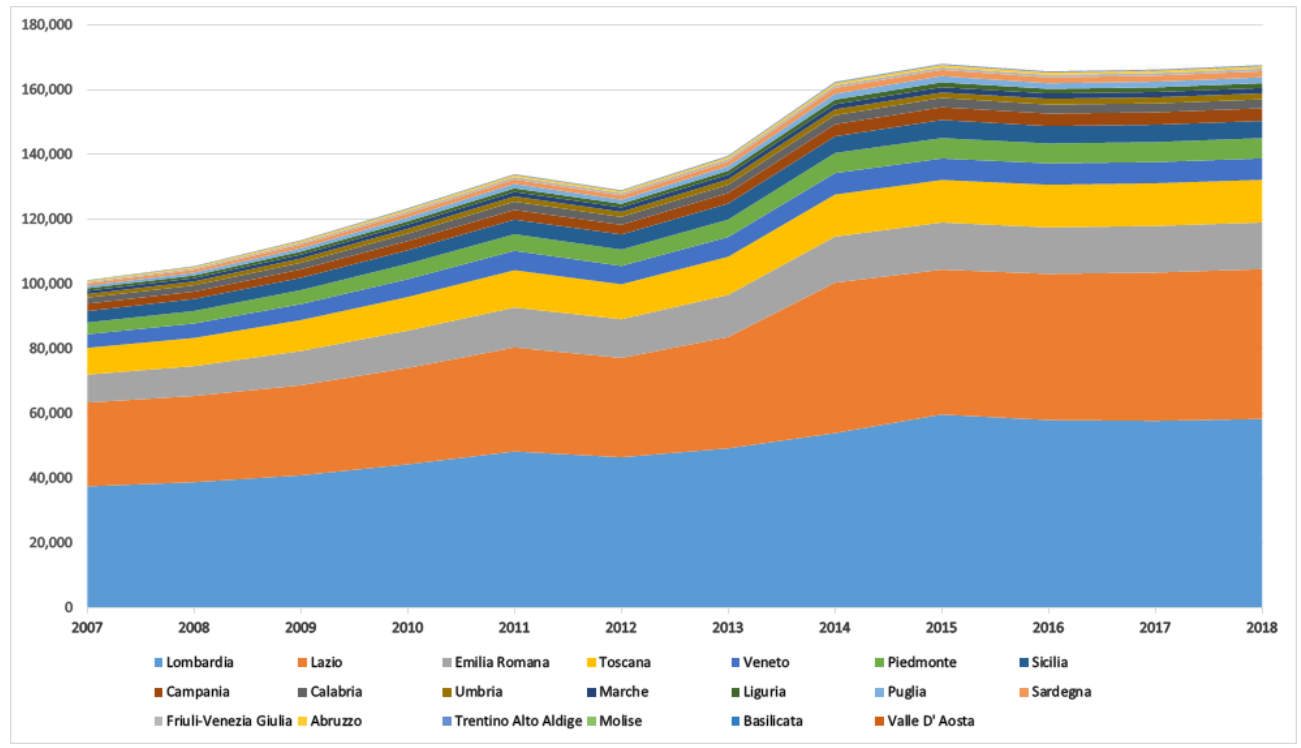

Figure 1: Regional Filipino Migrant Stock 
Figure 2 shows the pattern of Filipino labor migrants over time. In the eleven-year period, the drastic regional changes were seen regarding the inflow of Filipino migrant labors per region. Filipino migrant labors were concentrated most at the center of Italy, in the region of Lazio during the beginning of the study. High labor migrant inflows were also recorded in the regions of Lombardy and Emilia Romana. The smallest number of Filipino labor migrant settlements were in the regions of Molise, Basilicata, and Valley D' Aosta. It can be observed that most of the regions had a surge in labor migration flow in the years 2009 and 2010 but followed by the drastic decrease in 2011. The nationwide decrease in the arrival of Filipino labor migrants was reflected almost uniformly at the regional level. The drastic drop in inflows started in the year 2011 and continued until the end of the period. All regions reported a decrease in the labor migrant inflow except for Basilicata.

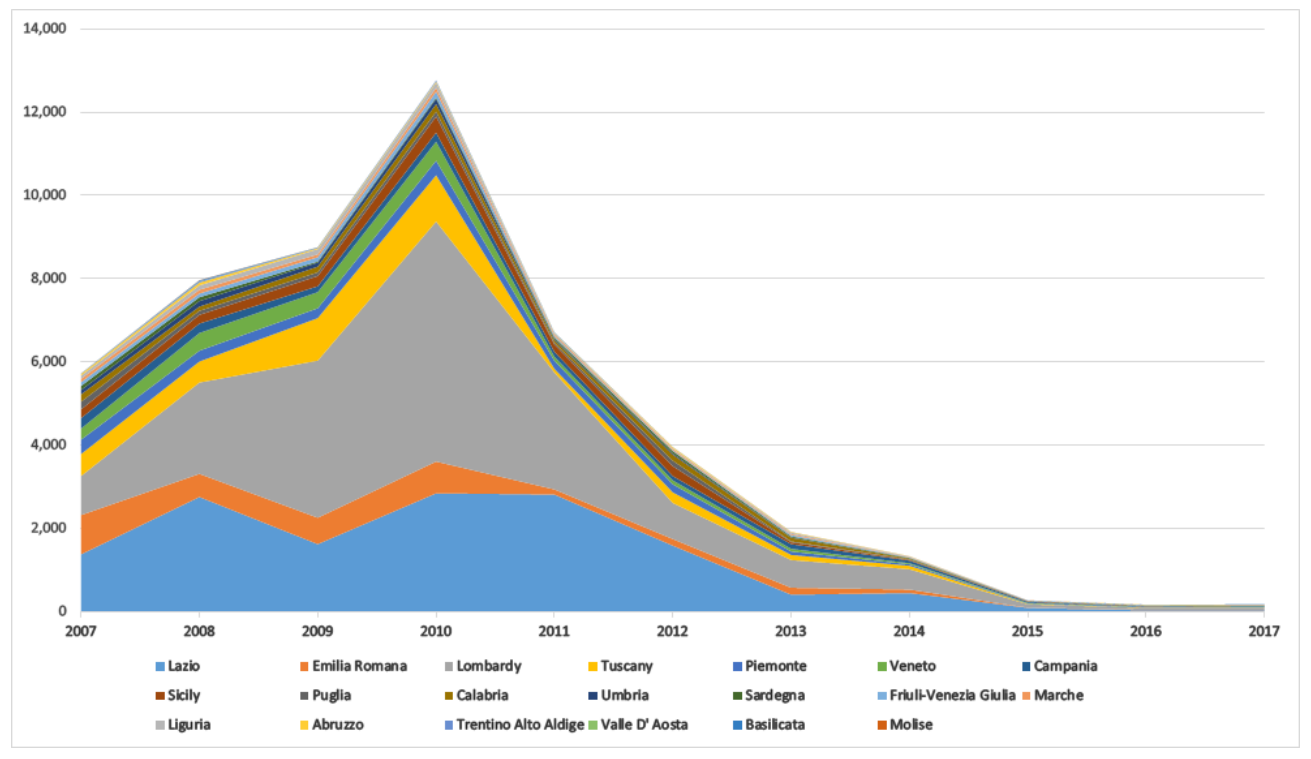

Figure 2: Inflow of Filipino Labor Migrants

\section{Data and Methodology}

\subsection{Data}

This research employes regional data retrieved from the ISTAT, the primary source of official statistics in Italy. Additional data for controls were obtained from the World Bank. The period of the research is from 2007 to 2017, covering all Italian regions at the level of NUTS-2 administrative division. A list of variables and their abbreviations is presented in Table 2.

The independent variables which are chosen based on the existing economic theories of labor migration and related studies are the total unemployed persons, real GDP, average housing cost in euros, and total Filipino migrant stock, all of which are obtained for each of the twenty regions in Italy. The first two independent variables are the economic variables that represent the macroeconomic environment of the region. The latter two variables, however, are used mainly as indicators that represent the geographical characteristics of the 
Table 2: Variables Description

\begin{tabular}{|c|c|c|}
\hline Variable & Description & Source \\
\hline RIFLM & Inflow of Filipino Labor migrant & ISTAT: Permits of stay to foreigners \\
\hline RGDP & $\begin{array}{l}\text { Gross Domestic Product at constant } \\
\text { prices }\end{array}$ & ISTAT \\
\hline $\mathrm{RU}$ & Unemployment & $\begin{array}{l}\text { ISTAT: Unemployed persons aged } 15 \text { years } \\
\text { and more }\end{array}$ \\
\hline $\mathrm{RE}$ & Employment & ISTAT: Labor Force \\
\hline RHC & $\begin{array}{l}\text { Housing cost (average monthly expen- } \\
\text { diture in euros) }\end{array}$ & ISTAT: Housing Costs \\
\hline RFP & Foreign population (except Filipinos) & $\begin{array}{l}\text { ISTAT: Migration and calculation of foreign } \\
\text { resident population and structure by citizen- } \\
\text { ship }\end{array}$ \\
\hline RFMS & Filipino Migrant Stock & $\begin{array}{l}\text { ISTAT: Number of Resident foreigners on the } \\
1^{\text {st }} \text { of January - Citizenship }\end{array}$ \\
\hline PGDPGR & Philippine GDP growth rate & World Bank: World Development Indicators \\
\hline
\end{tabular}

region. These two sets of variables highlight the various differences between regions. The relationships between the dependent variable of the research, which is the regional annual inflow of Philippine labor migrants, and these independent variables are examined to define which of these are the significant determinants of Filipino labor migration, the corresponding direction of the relation and its magnitude.

\section{Dependent Variable}

- Regional Inflow of Filipino Labor Migrants: It refers to the total number migrants from the Philippines moving to Italy for labor reasons, as reported in the ISTAT database. The figure refers to the total number of male and female migrants, measured per year and region.

\section{Independent Variables}

- Regional Real Gross Domestic Product: The figures are the annual GDP in millions of euros at constant prices of 2010. This refers to the inflation-corrected market value of all products and services that are produced in each region, for the reporting period.

- Regional Unemployment: Refers to the total number of unemployed persons reported per region (the total figures for all citizens aged 15 years old and above).

- Regional Housing Cost: Represents the average monthly expenditure on housing as measured in euros per region.

- Regional Filipino Migrant Stock : It is the total number of Filipinos living in each Italian regions. The figure also refers to the total number of male and female Filipinos, measured per year and region. This research adopts the definition of European Commission (2003) for migrant stock which is the "number of migrants in a given area on a certain date of the year in question". Hence, the total Filipino migrant stock refers to the total Filipino population living in each region in a certain year. 


\section{Instruments}

- Philippine's Growth Rate of Real GDP: Refers to growth rate of the Philippines' GDP measured at constant 2010 U.S. dollars.

- Regional Employment: Refers to the total number of employed persons reported per region (the total figures for all citizens aged 15 years old and above).

- Regional Foreign Population: Refers to the total foreign residents, except the number of Filipinos, living in the Italian regions. The figure also refers to the total number of male and female foreigners, measured per year and region.

\subsection{Model and Estimation Strategy}

This paper adopts two empirical models both test the different indices that drive the regional inflow of Filipino labor migration. The first empirical model employs static data analysis. The second model is a dynamic panel data analysis to handle possible issues of endogeneity. These estimates consider 11 years and 20 Italian regions.

The first empirical model of this research uses the following general form:

$$
\begin{array}{r}
\log \left(R I F L M_{t}\right)=\beta_{0}+\beta_{1} \log \left(R G D P_{t}\right)+\beta_{2} \log \left(R U_{t}\right)+ \\
\beta_{3} \log \left(R H C_{t}\right)+\beta_{4} \log \left(R F M S_{t}\right)+\epsilon_{t}
\end{array}
$$

where $R I F L M_{t}$, the dependent variable, refers to the regional inflow of Filipino labor migrants in year $t$. The independent variables are regional real GDP $\left(R G D P_{t}\right)$, regional unemployment $\left(R U_{t}\right)$, regional housing costs $\left(R H C_{t}\right)$, and regional Filipino migrant stock $\left(R F M S_{t}\right)$ in year $t . \epsilon_{t}$ is the error term in year $t$.

To measure the impact of regional indicators - GDP, housing costs, unemployment, and Filipino migrant stock on the total labor migrant inflow per region, double log regression is used. With the model, the elasticities of the independent variables in relation to the dependent variable can be efficiently identified. Since the research aims to quantify the responsiveness of the inflow of labor migrants, the elasticities are represented by the independent variables' coefficients. The model gives us direct results and by purely analyzing the coefficients, it shows the estimated correlation between percent change in the regional inflow of Filipino labor migrants to a percent change in an independent variable, holding the other independent variables constant. The coefficients also show the directions, magnitudes and patterns that are observed in various Italian regions. In the regression models presented in this paper, heteroskedasticity and multicollinearity are also checked.

The second set of models used in this research is a dynamic panel data approach, specifically the generalized method of moments (GMM). The xtabond2 program in STATA brings more flexibility in fine-tuning the results. With the program, robust standard errors are obtained by using Windmeijer (2005)'s sample correction, Sargan-Hansen's over-identifying restriction test is used, the nonexistence of serial correlation is proven and finally, power of the instrument matrix is enhanced (Roodman, 2009). This method allows the researcher to control for possible endogeneity issues. The model also qualifies the GMM specifics which include the following: $\mathrm{N}>\mathrm{T}$ (the number of groups is greater than the time span), the use of instrumental variable (IV) in estimation, exogenous instruments and instruments lower than or equal to $\mathrm{N}$. 
The dynamic model assumes the following general form:

$$
\begin{gathered}
\ln Y_{i, t}=\Phi Y_{i, t-1}+\gamma Z_{i, t}^{\prime}+\beta X_{i, t}^{\prime}+d_{t}+\varepsilon_{i, t}, \\
i=1,2, \ldots, N ; t=1,2, \ldots, T
\end{gathered}
$$

where $Y$ is the inflow of Filipino labor migrant, $Y_{i, t-1}$ is the first lagged value of $Y, Z^{\prime}$ is the vector of the control variables, $X^{\prime}$ is the vector of the explanatory variables, $d$ is the year dummies and $\varepsilon$ is the error term. This dynamic model allows us to use the lagged value of the dependent variable as an independent variable. Together with the regional values for unemployment, real GDP, housing cost and Filipino migrant stock, these comprises the vector of explanatory variables. Control variables are the Philippine GDP growth rate, regional total employment, and foreign population without Filipinos.

\section{Presentation and Discussion of Results}

\subsection{Static Models}

This subsection presents the results for the static estimates. The general observations are summarized into several points. First, regional unemployment and real GDP, although mostly positively correlated to the inflow of labor migrants, are not statistically significant determinants of the labor migration flow. Second, the regional housing cost has an inverse relationship with the migrant labor inflow, however, it is also statistically insignificant. Finally, regardless of control variables in the model, all simulations resulted in a significant Filipino migrant stock at a $99 \%$ level of confidence, albeit it is inversely correlated with the dependent variable. Table 3 identifies the significant variables, their corresponding

\begin{tabular}{|c|c|c|c|c|c|c|c|c|}
\hline & (1) & $(2)$ & (3) & (4) & (5) & (6) & (7) & (8) \\
\hline \multirow{2}{*}{ Unemployment(ln) } & ) 0.023 & 0.023 & 0.102 & 0.472 & 0.102 & 0.472 & 0.491 & 0.491 \\
\hline & -0.866 & -0.866 & -0.841 & -0.829 & -0.841 & -0.829 & -0.832 & -0.832 \\
\hline \multirow[t]{2}{*}{$\operatorname{GDP}(\ln )$} & -0.286 & -0.286 & 0.784 & 0.825 & 0.784 & 0.825 & 1.237 & 1.237 \\
\hline & -3.385 & -3.385 & -4.507 & -3.905 & -4.507 & -3.905 & -4.427 & -4.427 \\
\hline \multirow{3}{*}{$\begin{array}{l}\text { Housing } \\
\text { Cost }(\ln )\end{array}$} & -0.868 & -0.868 & -0.851 & -1.837 & -0.851 & -1.837 & -1.798 & -1.798 \\
\hline & & & & & & & & \\
\hline & -2.029 & -2.029 & -2.058 & -1.8 & -2.058 & -1.8 & -1.824 & -1.824 \\
\hline \multirow{2}{*}{$\begin{array}{l}\text { Filipino Migrant } \\
\text { Stock }(\ln )\end{array}$} & $-1.984^{* * *}$ & $-1.984^{* * *}$ & $-2.019 * * *$ & $-1.988 * * *$ & $-2.019 * * *$ & $-1.988 * * *$ & $-2.002^{* * *}$ & $-2.002^{* * *}$ \\
\hline & -0.544 & -0.544 & -0.553 & -0.468 & -0.553 & -0.468 & -0.478 & -0.478 \\
\hline Observations & 220 & 220 & 220 & 220 & 220 & 220 & 220 & 220 \\
\hline R-squared & 0.804 & 0.804 & 0.804 & 0.808 & 0.804 & 0.808 & 0.808 & 0.808 \\
\hline $\begin{array}{l}\text { Philippine GDP } \\
\text { growth rate }\end{array}$ & no & yes & no & no & yes & yes & no & yes \\
\hline Employment & no & no & yes & no & yes & no & yes & yes \\
\hline $\begin{array}{l}\text { Foreign Migrant } \\
\text { Stock }\end{array}$ & no & no & no & yes & no & yes & yes & yes \\
\hline
\end{tabular}

Table 3: Results of Static Panel Data Models

Note: Dependent variable is the level of Filipino labor migration. Robust standard errors are in parentheses. *** indicates $1 \%$ significance level.

relationships with the dependent variable, elasticities and controls. Column 1 presents the baseline results, i.e. the regression run without controls. Columns 2, 3 and 4 are the models with one control in the model - Philippine GDP growth rate, employment and foreign population, respectively. Finally, columns 5 to 7 contains the results for simulations with 
gradually increased controls, and column 8 contains all of the control variables.

\subsection{Dynamic Models}

Table 4 contains the results of the simulations for the dynamic panel models. These models are estimated by using the difference GMM. In particular, the results in Table 4 used the one-step difference GMM (Blundell \& Bond, 1998). The choice for the variant of estimators comes from applied works which still use the same one-step estimates. This is because simulation studies imply moderate efficiency gains, making the one-step just as relevant as the two-step variant. The advantage of the model includes robust standard errors, tested the validity of instruments, and proven the absence of serial autocorrelation. These

Table 4: Results of Dynamic Panel Models with Difference GMM

\begin{tabular}{lccccc}
\hline & $(1)$ & $(2)$ & $(3)$ & $(4)$ & $(5)$ \\
Lag of Labor Migration(ln) & $0.498^{* * *}$ & $0.677^{* *}$ & $0.775^{* * *}$ & $0.764^{* * *}$ & $0.466^{*}$ \\
& -0.115 & -0.245 & -0.136 & -0.167 & -0.25 \\
Unemployment(ln) & & $12.646^{* *}$ & $15.067^{* *}$ & $14.388^{* *}$ & $18.916^{*}$ \\
& & -5.704 & -6.452 & -5.507 & -9.989 \\
GDP(ln) & & & 10.134 & 8.902 & $29.435^{*}$ \\
& & & -16.328 & -16.08 & -16.804 \\
Housing Cost(ln) & & & -4.495 & 4.654 \\
& & & & -7.986 & -9.803 \\
Filipino Migrant Stock(ln) & & & & & $-7.403^{* *}$ \\
& 180 & 180 & 180 & 180 & -3.342 \\
\hline Observations & yes & yes & yes & yes & yes \\
Year Dummies & 0.845 & 0.854 & 0.594 & 0.576 & 0.503 \\
Arellano-Bond test (AR2) & & & & & \\
Hansen Test of over identification & 0.05 & 0.142 & 0.219 & 0.179 & 0.091 \\
\hline Note: Dependent variable is the level of Filipino labor migration. Robust standard errors are in \\
parentheses. ${ }^{* * *}, * *$, and ${ }^{*}$ stand for $1 \%, 5 \%, 10 \%$ significance level, respectively.
\end{tabular}

one-step difference simulations make use of the dependent variable which is the log of the regional inflow of Filipino labor migrants, endogenous variable as the one year lag of the dependent variable, which is also an explanatory variable. The other explanatory variables are unemployment, real GDP, housing cost and Filipino migrant stock. The internal instrument is the lag of the dependent variable. While the external instruments are Philippine GDP growth rate, employment and foreign migrant stock without Filipinos.

\subsection{Discussion of the Results}

ISTAT records show that the number of Filipino labor migrants arriving in Italy has decreased over time. Notwithstanding erratic surges in the years 2009 and 2010, the overall trend for the scope of the study is the decreasing figures. The surge in migration in those years was also unprecedented given the 2008 financial crisis that caused a global recession. This drastic overall decrease motivates this research to study the role of the destination region's geographical and economic indicators in the inflow of Filipino labor migrants.

Previous scholars have studied the different relationships between indicators of the destination countries and the inflow of labor migrants at the national level. McKenzie et al. (2014) establishes the significant and positive relationship between these two variables (destination countries indicators and national level labor migrant inflow) for Philippine labor migrants. 
In the static models, the results find no relationship between Italy's economic performance, as measured by the regional real GDP and regional unemployment with the inflow of migrant labors. Furthermore, this research finds no consistent economic predictors for the inflow of labor migrants. This lack of responsiveness of Filipino labor migrant inflow to economic variables is parallel with the findings of Daveri \& Faini (1999) and Fachin (2007) in their studies of Italian migration. Respectively, their research show that in the southern regions, the unemployment has no effect on migration during the period 1970-1989, and has a feeble influence during the years between 1973 and 1996.

In the industrialized regions, low-skilled job vacancies influence the flow of international labor migration, as discussed by Massey et al. (1993) and Jennissen (2004). However, the inflow of Filipino labor migrants reacts to regional unemployment in a positive manner. The opposite findings in this paper could offer labor substitution as an explanation. The substitution of the Filipino migrants for other foreign labor migrants may be the underlying factor that contributes to this unexpected finding. Foreign labor migrants are paid lower wage rates compared to locals. Thus, the unemployment in various regions may serve as a reverse signal for potential Filipino labor migrants to grab the opportunity in offering lower-cost labor in the sectors they are traditional known for such as child and elderly care, domestic works, and food and hospitality. Moving on with the two demographic variables which are housing cost and total Filipino migrant stock, the results are more consistent in terms of the direction of the relationship as compared to the economic variables used. This observation is in parallel with the findings of Etzo (2011) regarding the responses of migrants to the various push and pull forces in regions.

Moreover, the static models (Table 3) with various controls still find Filipino migrant stock as a significant driver of Filipinos labor migration. This is consistent with the arguments of many scholars such as MacDonald \& MacDonald (1964) and Biagi \& Dotzel (2018) about chain migration or beaten path. It is the existence of the Filipino communities in various Italian regions that drives the migration of Filipino labor. Although this finding is consistent across models, the inverse relationship between the dependent variable and the regional Filipino migrant stock is unexpected: as the total Filipino migrant stock increases, the inflow of labor migrants decreases. In the context of networks and connections, but not in the context of employment competition, this is counter-intuitive since having a network reduces the cost of finding a job. Etzo (2011) explains that migrants who are dependent on social networks for employment may not be applicable in the recent migrations due to the demand for specialized skills. This research suggests that modern technology such as the advances in computers may also play a role in the weakening of social networks as job postings and vacancies can be easily found across the world wide web. Another rationalization offered by this research is the existence of numerous public and private employment agencies in the Philippines, as discussed in the first half of the paper, may contribute to this direction of the relationship.

An explanation of the non-influence of the regional housing cost to migration inflow is offered by Etzo (2011). He argues that an increase in housing cost for immigrants including both monetary and non-monetary costs deters them from settling in a particular location. Numerous studies such as Sim (2000), Andersen et al. (2013), and Potepan (1994) cite the importance of housing location and cost as a predictor variable for migrant settlement in general. Also, an interesting finding by Andersson \& Nilsson (2011) indicates that instruments, which may be used intentionally or non-intentionally, such as the access to the labor 
market and the right to housing are used to control for migration inflow. Since various housing restrictions may apply to non-locals, which makes obtaining affordable housing difficult for migrants (van der Vlist et al., 2011), and generally, migrants receive lower wages compared to the locals.

To further examine the validity of the results in the static models and rule out probable endogeneity problems, this research utilized a more sophisticated analysis in the form of dynamic panel data estimators difference GMM. Throughout the simulations, pointers for using the GMM are strictly followed. In Table 4, it is indicated that the Sargan-Hansen estimates, which test for the overidentification of restrictions, all resulted to satisfactory figures, proving that the instrument sets used in the models were good and valid. The Arellano-Bond test (AR2) in first differences also provided suitable figures, indicating there is no second-order serial correlation for all simulations.

At the dynamic model in Table 4 column 5 , three variables - lag of labor migration inflow, regional unemployment and real GDP resulted in significant results, at a $10 \%$ level of confidence. The significant relationship between the unemployment and inflow of Filipino labor migrant remains to be positive, in the same direction as the results in the static model. This shows that regional unemployment positively and, in the case of the dynamic model, significantly drives the inflow of migrant labor. The same interpretation can be claimed for the relationship between regional real GDP and the lag of migrant labor inflow. Finally, the Filipino migrant stock remains to be significant, even in the dynamic models, but at a lower level of confidence.

After running various estimates by using static and dynamic models, both sets of estimators conclude the very same driver for Filipino migration: it is the Filipino migrant stock in various regions that influences migration inflow. As the results show, the Filipino migrant workers react more significantly to a demographic variable rather than the economic variables of the regions. This study offers three possible explanations. First, the unique dynamics between the Philippines's labor exporting policies and the willingness of Filipinos to migrate abroad for work makes the decision process on where to effectively work easier. As encouraged by the Philippine government's development policies and cultural Filipino mentality, regardless of the region of destination, as long as the work is overseas, labor migration is in line with the Filipinos' and their government's policies of exporting labor. Therefore, the first country of destination is still considered a triumph - hitting two goals in one step. It fulfills the goals to be in a better working environment and at the same time, the possibility of acquiring citizenship in the host country for long term migrants. Second, the results may also be explained by the type of migrant worker. For the first time migrant workers who are dependent only on privately-run agencies to find employment abroad, the destination is a secondary concern, next to the economic gains which is a potentially large income. If the migrant workers are more experienced and have access to better information about employment vacancies and the destination region, the reliance on private employment agencies for jobs abroad lessens or altogether vanishes. Third, the internal character or attitude of the Filipino labor migrant may play a role in deciding which region to settle in. The personal utility of the individual labor migrant could be the explanation for such behavior. For some labor migrants, having a network is the most important consideration to decrease the monetary and non-monetary cost of moving. Other migrants may consider the probability of employment more important than social connections. In the end, the variations of the inflow of Filipino labor migrants and the differences in responsiveness to 
the Italian regional indicators may depend on both the intrinsic and extrinsic factors.

\section{Conclusions}

The results of this study provide a basis for understanding the preferences and behavior of Filipino labor migrants migrating to Italy in response to regional economic and geographical indicators. This study finds support and contradictions from the migration theories in explaining the inflow of Filipino labor migrants using different variables. The contrasting findings can be interpreted as either an indication of a new flourishing trend in labor migration flow among a very specific migrant population or simply outliers in a relatively small migrant group.

The analysis leads to the following conclusions. First, the compilation of past and present findings regarding the drivers of migration to Italy infers the existence of a cyclical pattern of reaction to different indicators over time. To recap, this study, for the period of 2007-2017, confirms the findings of Salvatore (1977) for the period between 1950 and 1960 regarding unemployment causing the variances in regional migration. While the results of this research contradict with that of the similar study of Furceri (2006) whose scope is between 1985 and 2001. For the housing cost indicator, contradictory findings are noted as well. Cannari et al. (2000) claims the housing cost as deterrent to migration, and Etzo (2011) cites that it is in fact a significant determinant, this research is in parallel with the former. The contradictory findings for the same geographical area but different periods of time support the inference of the cyclical pattern. The second conclusion is that the inflow of Filipino labor migrants responds differently to various variables. Between static and dynamic estimators, this paper finds that although the variations among regions influence Filipino labor migration flow, it is the variable type that significantly drives migration. A demographic variable, which is Filipino migrant stock, resulted in to be more significant in influencing the inflow of Filipino labor migrants in both static and dynamic analyses.

This study contributes to the relatively new niche in the literature that considers the spatial dimension of labor markets by giving a specific migration angle - Filipinos laborers on regional scale. Through investigating in a region-specific scale, there is more comprehension on the ongoing phenomenon.

Since labor migration, particularly to Italy, has been a subject of great scrutiny and policy debates, the results of this paper would be useful for regional migration policies and reception. The demographics of Italian regions all show the same picture: excessive outmigration to the North of Italy or abroad, increasing older population and decreasing younger population. The entry of migrant labor continues to fill in the much-needed demand for labor, chiefly for unskilled jobs. As cited in numerous studies in the migration literature, the jobs that these migrants normally take are rather complementary, therefore, they are not a threat to the employment of the locals. With the above findings, migrant reception and treatment could be adjusted on a regional scale. By tailoring regional policies to elicit the needed migrant flow, regions can address the problems of changing demographics, and labor supply shortage.

The results also suggest that we still have a long way to go as the study is limited by the data available. Though the research period encompasses eleven years, from 2007 to 2017, expanding the scope to a longer period is highly encouraged to yield stronger results. Running the analysis, for a twenty or thirty-year period is another viable option for future 
researchers. Additional avenues for future studies include, but is not limited to, expanding the scope of migrants from a single ethnicity to several macro groups, such as South-East Asian, West African or Eastern European migrants in Italy. Another equally viable option is to segregate the inflow of migrants by gender, education level or conduct cross-country studies on migration elasticities. Future research could also be devoted to analyzing how migration determines regional economic health. This would be a beneficial addition to the migration literature since the importance and contribution of migrants is continuously challenged.

\section{References}

Andersen, H. S., Turner, L. M., \& Søholt, S. (2013). The Special Importance of Housing Policy for Ethnic Minorities: Evidence from a Comparison of Four Nordic Countries. International Journal of Housing Policy, 13(1), 20-44. doi:10.1080/14616718.2013.764659

Andersson, H. E., \& Nilsson, S. (2011). Asylum Seekers and Undocumented Migrants' Increased Social Rights in Sweden. International Migration, 49(4), 167-188. doi:10.1111/j.1468-2435.2009.00586.x

Bauer, T., Epstein, G. S., \& Gang, I. N. (2005). Enclaves, Language, and the Location Choice of Migrants. Journal of Population Economics, 18(4), 649-662. doi:10.1007/s00148-005-0009-z

Beets, G., \& Willekens, F. (2009). The Global Economic Crisis and International Migration: An Uncertain Outlook. Vienna Yearbook of Population Research, 7(1), 19-37.

Bertola, G. (2000). Labour Markets in the European Union. CESifo Forum, 1(1), 9-11.

Biagi, B., \& Dotzel, K. R. (2018). Theoretical Advances on Interregional Migration Models. In B. Biagi, A. Faggian, I. Rajbhandari, \& V. Venhorst (Eds.), New Frontiers in Interregional Migration Research (The Regional Science Series) (pp. 21-47). Springer, Cham. doi:10.1007/978-3-319-75886-2_2

Biagi, B., Faggian, A., \& McCann, P. (2011). Long and Short Distance Migration in Italy: The Role of Economic, Social and Environmental Characteristics. Spatial Economic Analysis, 6(1), 111-31. doi:10.1080/17421772.2010.540035

Blundell, R., \& Bond, S. R. (1998). Initial Conditions and Moment Restrictions in Dynamic Panel Data Models. Journal of Econometrics, 87(1), 115-43. doi:10.1016/S03044076(98)00009-8

Burridge, P., \& Gordon, I. (1981). Unemployment in the British Metropolitan Labour Areas. Oxford Economic Papers, 33(2), 274-27. doi:10.1093/oxfordjournals.oep.a041509

Cannari, L., Nucci, F., \& Sestito, P. (2000). Geographic Labour Mobility and the Cost of Housing: Evidence from Italy. Applied Economics, 32(14), 1899-1906. doi: $10.1080 / 000368400425116$ 
Chiswick, B. R., \& Miller, P. W. (2005). Do Enclaves Matter in Immigrant Adjustment? City \& Community, 4(1), 5-35. doi:10.1111/j.1535-6841.2005.00101.x

Daveri, F., \& Faini, R. (1999). Where Do Migrants Go? Oxford Economic Papers, 51(4), 595-622. doi:10.1093/oep/51.4.595

Dobson, J., Latham, A., \& Salt, J. (2009). On the Move? Labour Migration in Times of Recession (Policy Network Paper). Policy Network. https://bit.ly/38zt1dz.

Eichengreen, B. (1993). Labor Markets and European Monetary Unification. In P. R. Masson \& M. P. Taylor (Eds.), Policy Issues in the Operation of Currency Unions (p. 130-162). Cambridge University Press. doi:10.1017/CBO9780511599194.007

Etzo, I. (2011). Determinants of Interregional Migration in Italy: A Panel Data Analysis (MPRA Paper No. 5307). University Library of Munich.

European Commission. (2003). Demographic Statistics: Definitions and Methods of Collection in 31 European Countries. European Commission.

Fachin, S. (2007). Long-run Trends in Internal Migrations in Italy: A Study in Panel Cointegration with Dependent Units. Journal of Applied Econometrics, 22(2), 401-28. doi:10.1002/jae.907

Furceri, D. (2006). Does Labour Respond to Cyclical Fluctuations? The Case of Italy. Applied Economics Letters, 13(3), 135-39. doi:10.1080/13504850500392925

Harris, J. R., \& Todaro, M. P. (1970). Migration, Unemployment and Development: A Two-sector Analysis. The American Economic Review, 60(1), 126-42.

Jennissen, R. P. W. (2004). Macro-economic Determinants of International Migration in Europe. Dutch University Press.

Kuhn, W. E. (1978). Guest Workers as an Automatic Stabilizer of Cyclical Unemployment in Switzerland and Germany. The International Migration Review, 12(2), 210-24. doi: $10.2307 / 2545604$

Lindio-McGovern, L. (2003). Labor Export in the Context of Globalization. International Sociology, 18(3), 513-34. doi:10.1177/02685809030183004

MacDonald, J., \& MacDonald, L. (1964). Chain Migration Ethnic Neighbourhood Formation and Social Networks. The Milbank Memorial Fund Quaterly, 42(1), 82-97. doi: $10.2307 / 3348581$

Massey, D. S., Arango, J., Hugo, G., Kouaouci, A., Pellegrino, A., \& Taylor, J. E. (1993). Does Housework Lower Wages? Evidence for Britain. Population and Development Review, 19(3), 431-66. doi:10.2307/2938462

McKenzie, D., Stillman, S., \& Gibson, J. (2010). How Important is Selection? Experimental VS. Non-Experimental Measures of the Income Gains from Migration. Journal of the European Economic Association, 8(4), 913-45. doi:10.1111/j.1542-4774.2010.tb00544.x 
McKenzie, D., Theoharides, C., \& Yang, D. (2014). Distortions in the International Migrant Labor Market: Evidence from Filipino Migration and Wage Responses to Destination Country Economic Shocks. American Economic Journal: Applied Economics, 6(2), 4975. doi:10.1257/app.6.2.49

Ministry of Labor and Social Policies. (2018). Foreigners in the Italian Labour Market $\left[8^{\text {th }}\right.$ Annual Report]. https://bit.1y/37mRzq4.

Niebuhr, A. (2003). Spatial Interaction and Regional Unemployment in Europe. European Journal of Spatial Development, 1-26.

Obstfeld, M., \& Peri, G. (1999). Regional Non-adjustment and Fiscal Policy: Lessons for EMU (Working Paper No. 6431). National Bureau of Economic Research.

Philippine Statistical Authority. (2018). 2017 Survey on Overseas Filipino. https:// bit.1y/2TX9Zdf.

Potepan, M. J. (1994). Intermetropolitan Migration and Housing Prices: Simultaneously Determined? Journal of Housing Economics, 3(2), 77-91. doi:10.1006/jhec.1994.1001

Reich, M., Gordon, D. M., \& Edwards, R. C. (1973). A Theory of Labor Market Segmentation. The American Economic Review, 63(2), 359-365.

Riva, E., \& Zanfrini, L. (2013). The Labor Market Condition of Immigrants in Italy: The Case of Lombardy. Revue Interventions Économiques. Papers in Political Economy, 47, 1-26. doi:10.4000/interventionseconomiques.1987

Rodriguez, R. M. (2010). The Emergence of Labor Brokerage: U.S. Colonial Legacies in the Philippines. In Migrants for Export: How the Philippine State Brokers Labor to the World (pp. 1-18). University of Minnesota Press.

Roodman, D. (2009). How to do Xtabond2: An Introduction to Difference and System GMM in Stata. The Stata Journal, 9(1), 86-136. doi:10.1177/1536867x0900900106

Salvatore, D. (1977). An Econometric Analysis of Internal Migration in Italy. Journal of Regional Science, 17(3), 395-408. doi:10.1111/j.1467-9787.1977.tb00510.x

Sanders, J. M., \& Nee, V. (1987). Limits of Ethnic Solidarity in the Enclave Economy. American Sociological Review, 52(6), 745-73. doi:10.2307/2095833

Sassen, S. (1991). The Global City: New York, London, Tokyo. Princeton University Press.

Sim, D. (2000). Housing Inequalities and Minority Ethnic Groups. In I. Anderson \& D. Sim (Eds.), Social Exclusion and Housing: Context and Challenges. Chartered Institute of Housing: Coventry.

Technical Education and Skills Development Authority. (2017). TESDA to Give Free Trainings to Returning OFWs [Press Release]. https://bit.ly/38ECpNd. 
van der Vlist, A. J., Czamanski, D., \& Folmer, H. (2011). Immigration and Urban Housing Market Dynamics: The Case of Haifa. The Annals of Regional Science, 47(3), 585-98. doi:10.1007/s00168-010-0396-2

Waldinger, R. (1994). The Making of an Immigrant Niche. International Migration Review, 28(1), 3-30. doi:10.1177/019791839402800101

Waldinger, R. (1996). Still the Promised City? African-Americans and New Immigrants in Post Industrial New York. Harvard University, Cambridge.

Windmeijer, F. (2005). A Finite Sample Correction for the Variance of Linear Efficient Two-step GMM Estimators. Journal of Econometrics, 126(1), 25-51. doi:10.1016/j.jeconom.2004.02.005

Yang, D. (2008). International Migration, Remittances and Household Investment: Evidence from Philippine Migrants' Exchange Rate Shocks. The Economic Journal, 118(528), 591630. doi:10.1111/j.1468-0297.2008.02134.x 